\title{
Testicular sonography and biopsy in the stallion - Indication, techniques and diagnostic relevance
}

\author{
C.P. Bartmann', H.-A. Schoon², K. Lorber' , Iris Brickwedel' and E. Klug'1 \\ ${ }^{1}$ Klinik für Pferde der Tierärztlichen Hochschule Hannover, Hannover; ${ }^{2}$ Institut für Veterinär-Pathologie der Universität Leipzig, Leipzig
}

\begin{abstract}
Summary
Transscrotal testicular ultrasonography and testicular biopsy as well as a clinical andrological evaluation were performed in six stallions referred to the clinic for routine castration prior to ablation of the testes and in nine stallions with azoospermia or clinically detectable disorders of the testis such as enlargement, asymmetria, pain or abnormalities of the tissue at palpation. The testicular biopsy was obtained using an automatic biopsy gun with the stallion under general anaesthesia, whereas testicular ultrasonography could be performed with the stallions restrained in an open sided stock without sedation. Testicular ultrasonography was found to have a high sensitivity in the diagnosis of testicular tumour, inflammation or intra- and extratesticular fluid accumulation. No correlation between the echogenicity of testicular parenchyma and sperm production could be found as yet. Testicular biopsy proved to be a valuable technique in fertility examination but due to its invasive character and the potential complications its application should be limited to cases which remain clinically, ultrasonographically and endocrinologically unclear. The differentiation of azoospermia represents a typical indication.
\end{abstract}

Keywords: $\quad$ Stallion, fertility, testis, ultrasonography, testicular biopsy, testicular histology, testicular disorders

\begin{abstract}
Hodenbiopsie und -sonographie beim Hengst - Indikation, Technik und diagnostische Relevanz
Bei sechs zur Kastration vorgesehenen Hengsten wurde eine transskrotale Ultrasonographie und unmittelbar vor Entnahme der Hoden eine Hodenbiopsie durchgeführt. Darüber hinaus wurden neun Hengste mit anläßlich der samenbiologischen Untersuchung festgestellter Azoospermie oder mit klinisch auffälligen Hodenveränderungen wie Schwellung. Asymmetrie, Schmerz oder abweichender Gewebekonsistenz diesen erweiterten Untersuchungsverfahren unterzogen. Dabei wurde die Hodenbiopsie mit Hilfe einer Schußautomatik an den allgemeinanästhesierten Hengsten vorgenommen, während die Hodensonographie bei allen Hengsten ohne Sedierung im Zwangsstand durchführbar war. Die Hodensonographie besaß eine hohe diagnostische Sensitivität bezüglich des Nachweises von Hodentumoren, einer Orchitis oder intra- und extratestikulärer Flüssigkeitsansammlungen. Bislang ergab sich keine Korrelation zwischen der sonographischen Textur des Hodenparenchyms und der Spermienproduktion.

Die Hodenbiopsie ist eine wertvolle Ergänzung in der Fertilitätsuntersuchung beim Hengst. Entsprechend ihres invasiven Charakters und potentieller Komplikationen solite die Indikation jedoch streng gestellt werden und erst bei diagnostischer Unklarheit nach Anwendung weniger invasiver Techniken gegeben sein. Dabei ist die Differenzierung der Azoospermie eine typische Indikation.
\end{abstract}

Schlüsselwörter: Hengst, Fertilität, Hoden, Ultraschall, Hodenbiopsie, Hodenhistologie, Hodenerkrankung

\section{Introduction}

Evaluation of infertility in the stallion has been carried out using many techniques including physical examination, semen analysis and bacteriological culture.

In addition to this, scrotal ultrasonography allows a differentiation between intra- and extratesticular pathology with a high degree of accuracy (Dascanio 1999). Testicular biopsy may be a useful tool in detecting disorders like germinal cell aplasia, germinal cell arrest, inflammation or testicular neoplasia. Furthermore, testicular biopsy is indicated for differentiating causes of azoospermia such as obstructive azoospermia from testicular azoospermia (Schill 1994; Bergmann and Kliesch 1998; Blanchard and Varner 1996). Three testicular biopsy techniques differing in the amount of tissue recovered and the invasiveness of the procedure have been described using the incisional biopsy, the split needle or tru-cut biopsy and the fine-needle aspiration biopsy (DelVento et al. 1992; Threlfall and Lopate 1993; Blanchard and Varner 1996).

Scrotal ultrasonography has proved to be a procedure which is easy to perform without risk for the stallion whereas testicular biopsy may involve a number of complications such as intratesticular haemorrhage, adhesion formation, induction of an im- mune reaction to spermatozoa and dissemination of neoplastic cells in those cases with tumour formation (Dascanio 1999). In spite of these risks, previous studies have demonstrated minimal damage to the function of the testis (Delvento et al. 1992) and the testicular biopsy was not found to be detrimental to future stallion fertility (Faber and Roser 1998). Although a sample may not be representative of the whole testis, Brinkhoff (1974) demonstrated that tissue samples taken using the technique described by Ippensen et al. (1972) and Smith (1974) were representative of the remaining organ.

\section{Materials and methods}

Testicular ultrasonography and testicular biopsy were performed in six fertile mature stallions without gross testicular lesions referred to the clinic for routine castration (group 1). Furthermore, clinical and ultrasonographical examination was carried out in nine stallions with clinical scrotal (fig. 1) or testicular symptoms (pain, uni- or bilateral swelling) or history of infertility (group 2). Some of these underwent semen evaluation and testicular biopsy (table 1). 
Testicular sonography

For ultrasonographic examination, stallions were restrained in an open-sided stock. Scrotal contents were evaluated through palpation. Both testes of each stallion were scanned using a 5.0 Mhz linear array transducer connected to an ultrasound system Aloka SSD 210 (Fa. Eickemeyer) and a 7.5 Mhz linear array transducer with an ultrasound scanner Sonoline Versa Pro (Fa. Siemens). Following lubrification of the contact surface of the probe with water-soluble gel, it was placed on the scrotal skin. The probe was first positioned vertically at the cranial pole of the testis and moved caudally. It was then positioned laterally at the testis and moved medially. The ultrasonogram was recorded on a videotape.

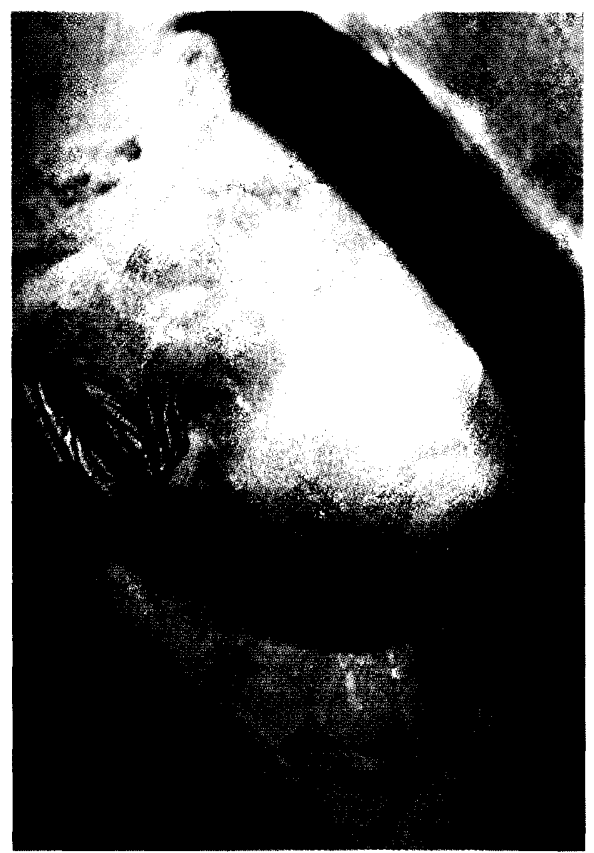

Fig. 1: Scrotal swelling and asymmetria in a stallion with unilateral orchitis.

Skrotale Umfangsvermehrung und Asymmetrie bei einem Hengst mit unilateraler Orchitis.

\section{Testicular biopsy}

Testicular biopsy was performed under general aanesthesia with the horse placed in dorsal recumbency. Following premedication with $1 \mathrm{mg} / \mathrm{kg}$ bwt xylazine (Rompun®, Fa. Bayer Vital, Leverkusen), anaesthesia was induced using diazepam $0.05 \mathrm{mg} / \mathrm{kg}$ bwt (Diazepam ratio $\AA$, Fa. ratiopharm, Ulm) and $2.2 \mathrm{mg} / \mathrm{kg}$ bwt ketamine (Narketan®, Fa. Chassot, Ravensburg) and maintained after intubation with oxygenized halothane (Halothan $®$, Fa. Hoechst, Wiesbaden). The scrotum was prepared for aseptic surgery.

In the six stallions without clinically apparent lesions (group 1 ), biopsy was obtained in one of the testis.

Group 2: in three stallions with unilateral testicular enlargement the clinically abnormal testis was taken for biopsy (table 1). In another three stallions without gross lesions but with azoospermia the left testis was selected for biopsy.

An automatic biopsy system Manan®) Pro-Mag 2.2 (Fa. Pflugbeil, Ottobrunn) with a 18-gauge side notch needle was used to collect a sample from the testis. An incision no larger than $0.3 \mathrm{~cm}$ was made in the scrotal skin as well as through the parietal layer of the vaginal tunic.

The biopsy needle was pushed through the tunica albuginea into the lateral part of the testicular parenchyma to avoid lacerating of a testicular artery (Ippensen et al. 1972; Smith

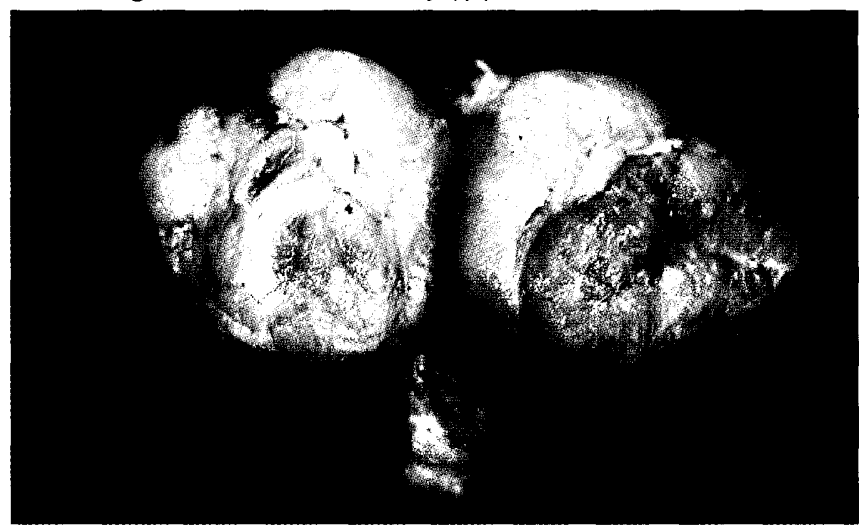

Fig. 2: Seminoma in a 19 year old stallion following castration. Neoplasia shows white colour in contrast to the dark regular parenchyma.

Seminom eines 19 Jahre alten Hengstes nach Kastration. Hodenparenchym dunkel, Neoplasie gelblich-weiß.

1974). In stallions with palpable or ultrasonographically detected irregular testicular structure the needle was inserted into this area. After shooting the needle into the parenchyma, it was removed from the testis and the tissue sample was immediately placed in $4 \%$ buffered formalin. The scrotal incision was not sutured.

Stallions of group 1 were bilaterally castrated following testicular biopsy.

Surgical treatment of stallions of group 2 depended on the results of ultrasonography and biopsy (table 1). Testicular tumours were diagnosed in two stallions (fig. 2). In a further stallion a testicular cyst was diagnosed. All were immediately castrated. A third stallion with testicular tumour was euthanized.

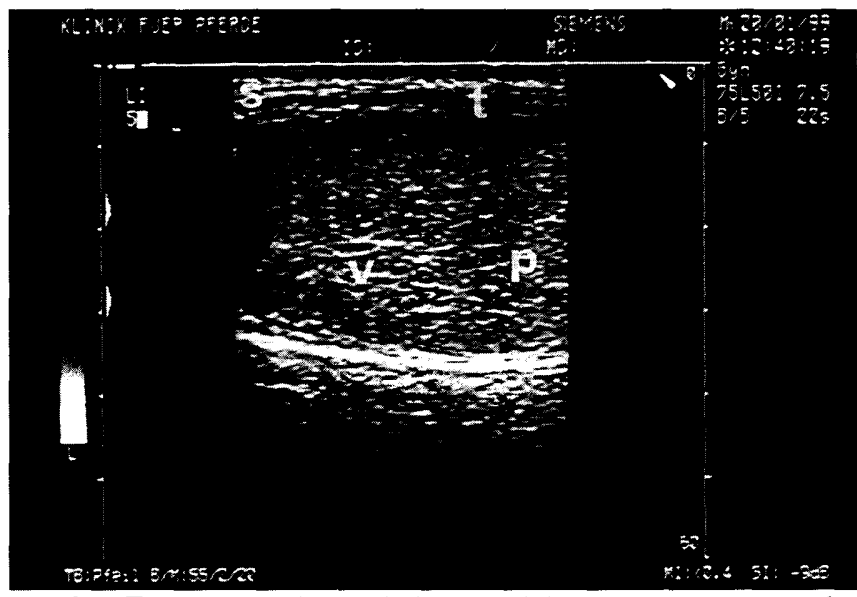

Fig. 3: Transversal ultrasonic image of the scrotal contents of a stallion using a 7.5- $\mathrm{MHz}$ linear transducer. Homogenous testicular parenchyma (p), scrotal skin (s), tunica albuginea (t) and central vein (v) can be identified.

Sonographischer Querschnitt des Skrotalinhaltes eines Hengstes mit einem 7,5 Mhz Linearschallkopf. Das homogene Hodenparenchym (p), die Skrotalhaut (s), die tunica albuguinea $(\mathrm{t})$ und die zentrale Hodenvene $(\mathrm{v})$ sind erkennbar. 


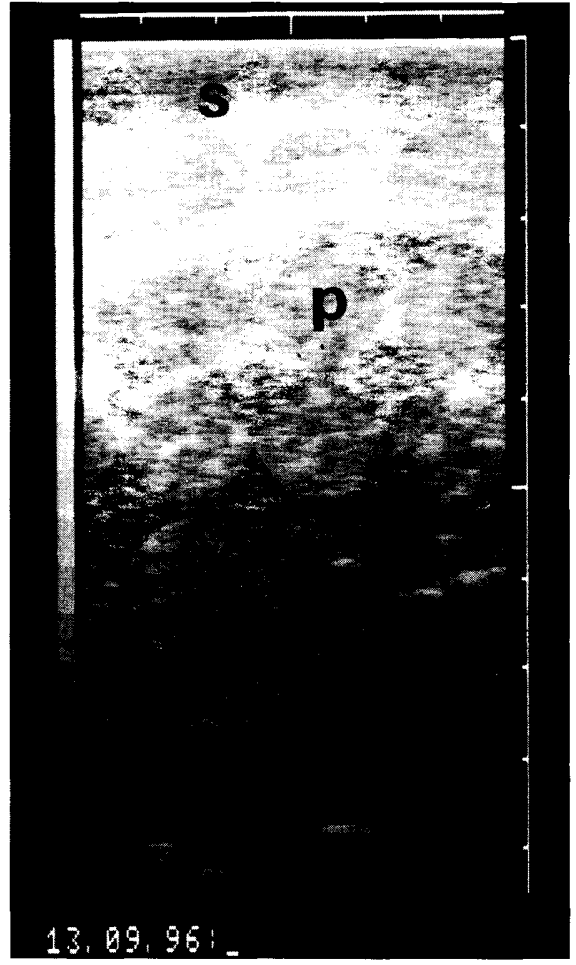

One stallion with orchitis was castrated unilaterally. One stallion with a hemoscrotum was treated medicamentally and three stallions with testicular degeneration were left untreated. Those three stallions with remaining testes after biopsy were monitored for three days postoperatively (body temperature, clinical and ultrasonographical testicular examination, white blood cell count) and than discharged from the clinic.

\section{Patho-histological techniques}

The tissues were fixed in $4 \%$ buffered formalin and embedded in paraplast using routine techniques. Formalin-fixative is preferred rather than Bouin's fluid for it allows the use of immunohistological techniques if necessary. Sections (also serials) were cut and stained by haematoxylin eosin. Additionally the following immunohistological methods were tested, comparing the findings of the whole testes with those of the biopsies: intermediate filaments (vimentin, desmin) and androgen receptors.

\section{Results}

Transscrotal testicular ultrasonographic evaluation could be performed in all of the 17 stallions restrained in an opensided stock without sedation.

In the six stallions of group 1, testicular parenchyma showed homogenous echogenicity and the central vein could be visualized in ultrasonographic cross-sections (fig. 3). During biopsy, three stallions had a mild haemorrhage from the testicular parenchyma. All showed immediate haemostasis. Castration of the six stallions and primary wound closure occured without complications.

Due to minimal size of biopsy and artefacts, interpretation was not possible in two of six biopsies of group 1 .

Sections of an adequate quality had a size differing from $4 \times 1 \times 1 \mathrm{~mm}$ (minimum) to $10 \times 1 \times 1 \mathrm{~mm}$ (maximum), containing
Fig. 4a (left) +b (right): Transscrotal ultrasonic images of a stallion with unilateral orchitis using a $5 \mathrm{Mhz}$ linear transducer.

a: Inflamd testis with severe edema of the scrotal skin (s). Inhomogenous binner reflexes with hyperechogenic spots in a hypoechogenic parenchyma (p) can be identified as a sign of inflammation and necrosis.

b: Contralateral testis without ultrasonic signs of abnormality.

Skrotalsonographie mit einem 5 Mhz Linearschallkopf bei einem Hengst mit einseitiger Orchitis a: Entzündeter Hoden mit deutlichem Odem der Skrotalhaut (s). Ein inhomogenes Binnenreflexmuster mit hyperechogenen Punkten in einem ansonst hypoechogenen Hodenparenchym (p) können als Anzeichen der Entzündung und Nekrose erkannt werden.

b: Der kontralaterale Hoden zeigt keine erkennbaren Veränderungen.

seminiferous tubules between 20 (minimum) and 60 (maximum). Most stages of the seminiferous epithelium cycle were present. In the lumina of a few tubules desquamated spermatogenic cells, mainly spermatids, appeared. Leydig cells of varying number and fibrous tissue were obvious between the seminiferous tubules. Clear spaces around the tubules were interpreted as shrinkage artefacts due to fixation. All immunohistological techniques revealed excellent results and identical findings in the biopsies and the whole testes (fig. $7 \mathrm{a}+\mathrm{b}$ ).

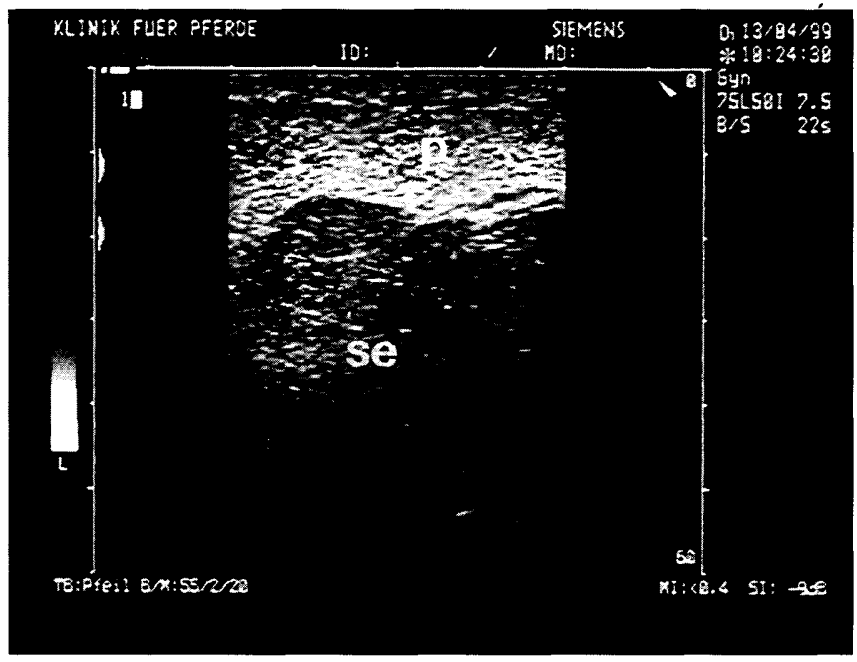

Fig. 5 Transscrotal ultrasonography in a stallion with testicular enlargement using a 7.5 Mhz transducer. A circumscribed, hypoechogenic area in the testicular parenchyma (p) was histologically found to be seminoma (se).

Skrotalsonographie eines Hengstes mit Hodenvergrößerung mit einem 7,5 Mhz Linearschallkopf. Ein umschriebener, hypoechogener Bereich im Hodenparenchym (p) wurde histologisch als Seminom (se) bestätigt. 

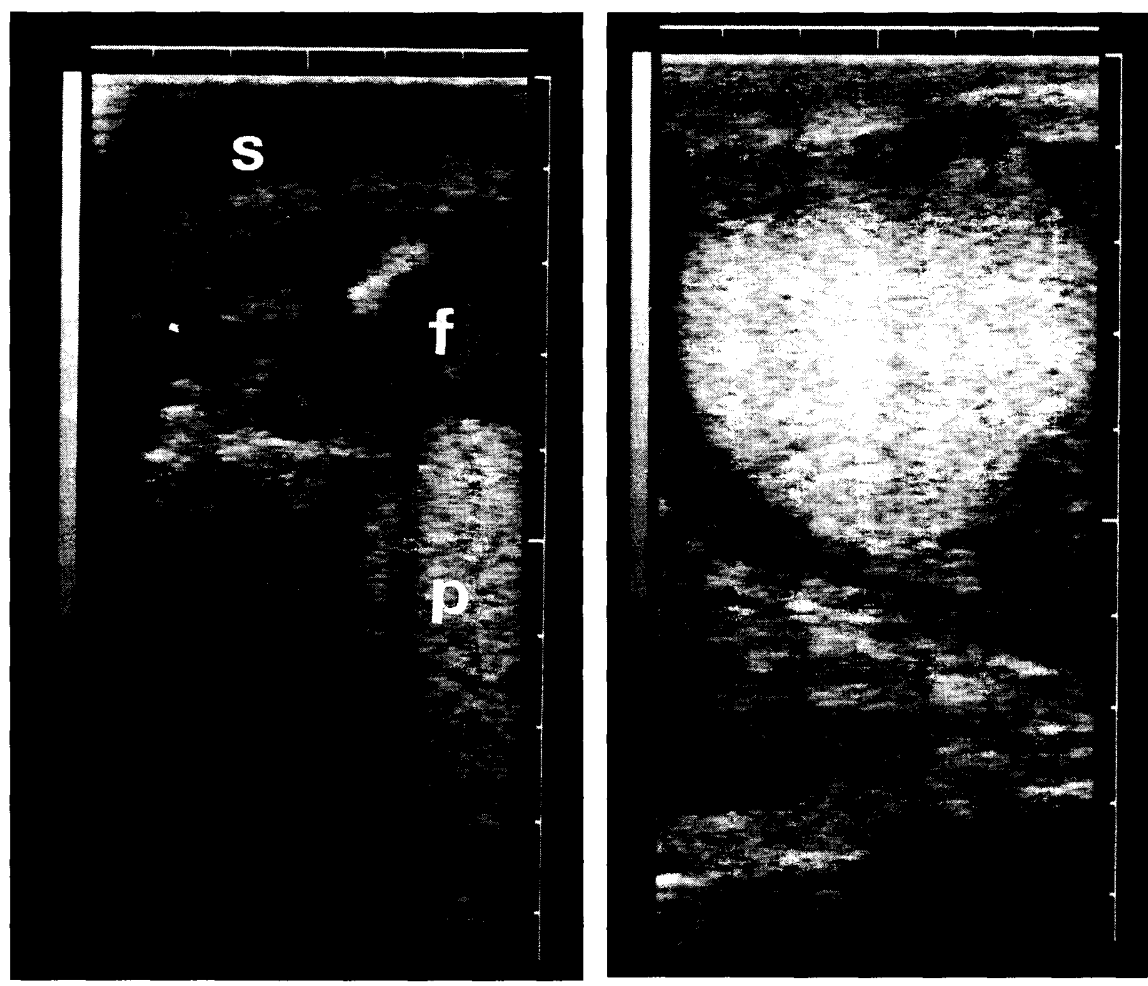

Fig. $6 a$ (left) +b (right): Transscrotal ultrasonic image of a stallion with a haemoscrotum following a kick using a $5 \mathrm{Mhz}$ linear transducer.

a: Fibrin $(f)$ is floating within accumulation of anechogenic free fluid within the scrotum. Scrotal skin (s) shows an edema. Testicular parenchyma is homogenous.

b: Due to resorption, free intrascrotal fluid and scrotal skin edema have been markedly reduced ten days later.

Transskrotale Sonographie eines Hengstes mit einem traumatisch bedingten Haemoskrotum mit einem $5 \mathrm{Mhz}$ Linearschallkopf.

a: In freier anechogener Flüssigkeit innerhalbs des Skrotums schwimmt Fibrin (f). Die Skrotalhaut (s) ist ödematös verdickt. Das Hodenparenchym ist unauffällig homogen. b: Nach zehn Tagen sind Ödem und Flüssigkeitsansammlung resorptionsbedingt deutlich reduziert.

Results of andrological examination of nine stallions with clinical disease of the testes or history of infertility (group 2) are presented in table 1. Irregular ultrasonographical appearance could be demonstrated in all of the stallions (fig. $4,5,6$ ) except those with azoospermia due to arrested spermatogenesis.

In those three clinical cases a severe degenerative damage of the testicular tissue was obvious. This could be found by means of testicular biopsy (Table 1 , no. $7,8,9$ ). All of the tubules present in the biopsy sections were affected in the same degree. The tubular lumina were lined by cuboid to flat sustentacular cells, only individual, mainly necrotic ger- minal cells remained. The lumina were mostly empty. The basement membrane was either thicker than normal or discontinous. The tubules were separated by a relatively large number of Leydig cells and a small amount of orderly arranged fibrous tissue. Atrophic processes leading to the diagnosis of an arrested spermatogenesis in one stallion were characterized by a missing of mature sperm cells (fig. 8 $\mathrm{a}+\mathrm{b})$. Only a few primary spermatocytes occured, some of them desquamating into the lumina. In two cases with the clinical diagnosis "azoospermia" the tubular lumina contained nearly exclusively Sertoli-cells, according to the diagnosis "Sertoli-cell-only-syndrome“ (fig. 9 a+b).
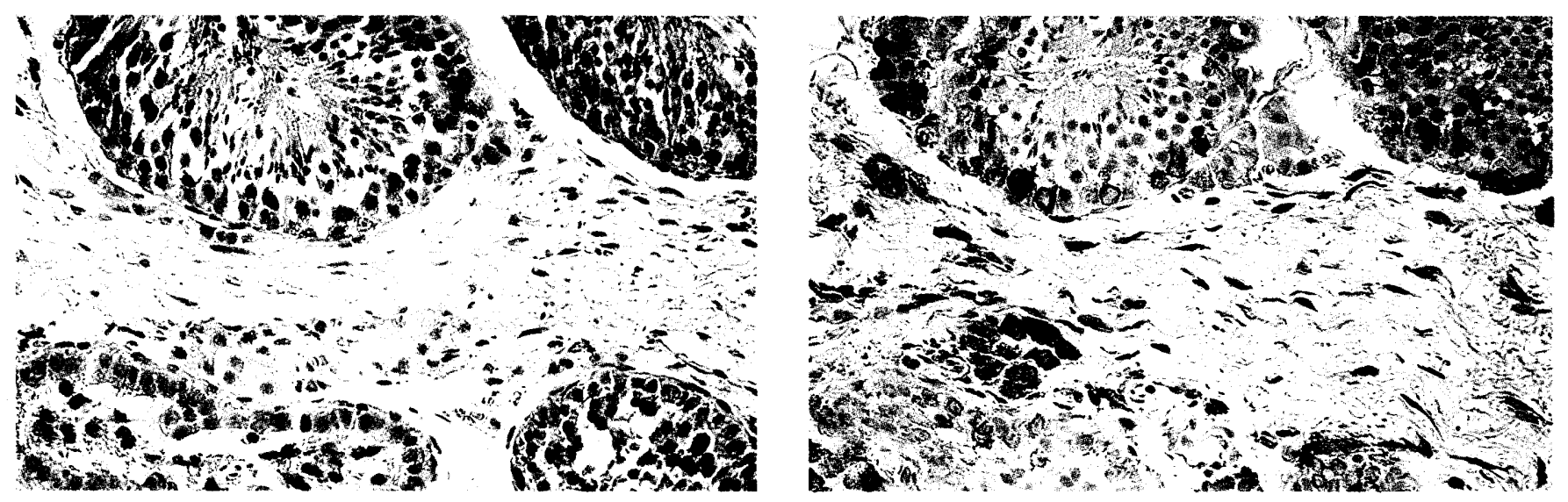

Fig. 7a (left) +b (right): Biopsy sample of an intact testis from a six year old stallion. In the lumina of the seminiferous tubules numerous spermatids are visible. Between the artificially separated tubules fibrous tissue and a few Leydig cells occur. Vimentin expression is present in the Sertoli cells, the fibrocytes and the Leydig cells.
a: HE staining, magnification 300x;
b: Immunohistology, Vimentin, magnification 300x

Biopsie des intakten Hodens eines sechsjährigen Hengstes. Im Lumen der Tubuli seminiferi sind zahlreiche Spermatiden erkennbar. Zwischen den separierten Kanälchen liegt Bindegewebe mit vereinzelten Leydigzellen vor. Eine Expression von Vimentin wird in Sertolizellen, Fibrozyten und Leydigzellen deutlich.

a: HE Färbung, Vergrößerung 300x; b: Immunhistologie, Vimentin, Vergrößerung 300x 

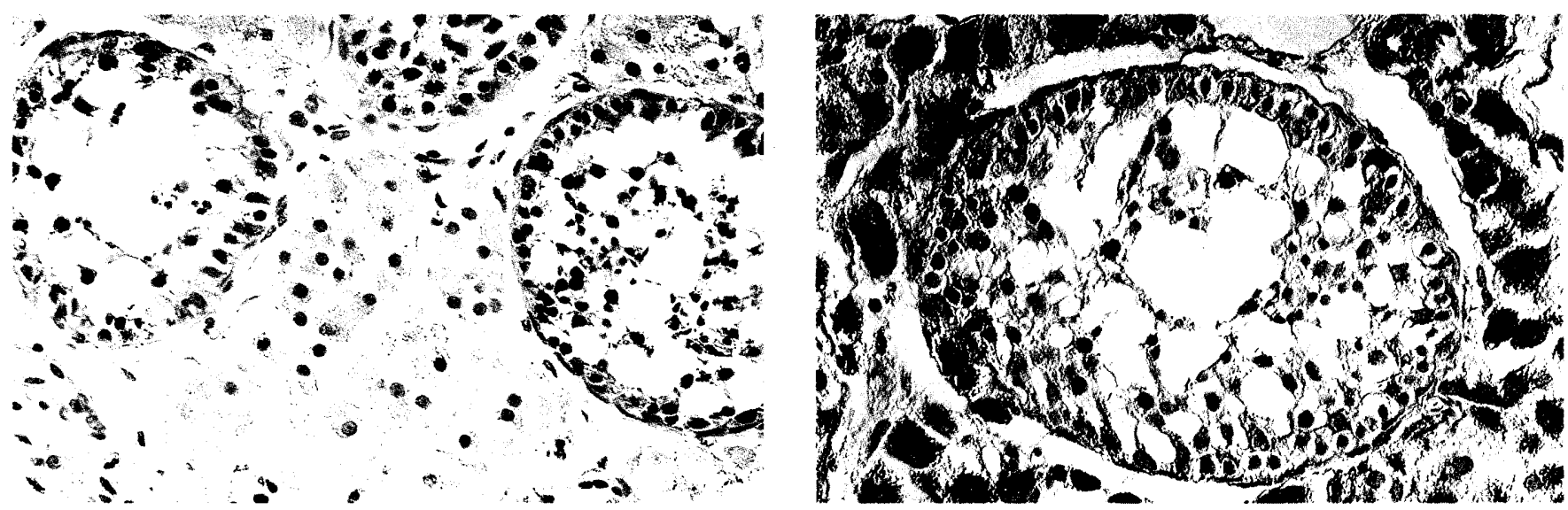

Fig. 8a (left) +b (right): Testicular biopsy sample from a five year old stallion (Table 1, no. 9), clinical diagnosis "azoospermia“. The tubules are lined by sustentacular cells and a few mainly necrotic and desquamated germinal cells indicating an arrested spermatogenesis. Numerous Leydig cells are visible between the tubules. Vimentin expression is present in the Sertoli cells, the fibrocytes and the Leydig cells.

a: HE staining, magnification 300x; b: Immunohistology, Vimentin, magnification 300x

Hodenbiopsie eines fünfjährigen Hengstes (Tabelle 1, nr. 9) mit der klinischen Diagnose "Azoospermie" Die Tubuli sind von Stützzellen umfaßt. Vereinzelte und überwiegend nekrotische und abgestoßene Keimzellen zeigen eine arretierte Spermatogenese an. Zwischen den tubuli sind zahlreiche Leydigzellen erkennbar. Eine Expression von Vimentin liegt in Sertolizellen, Fibrozyten und Leydigzellen vor.
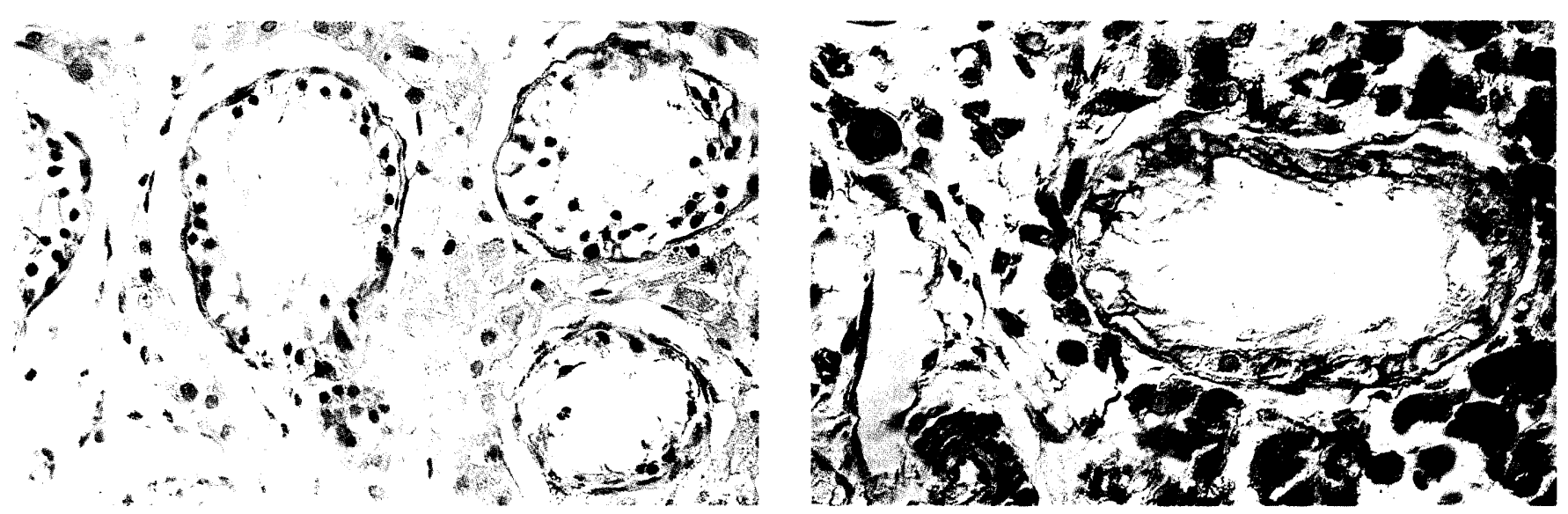

Fig. 9a (left) +b (right): Testicular biopsy sample from a 10 year old stallion (Table 1, no. 7), clinical diagnosis "azoospermia“. The seminiferous tubules contain nearly exclusively Sertoli cells, which leads to the diagnosis "Sertoli-cell-only-syndrome". Additionally a hyperplasia of the Leydig cells is visible. Vimentin expression is present in the Sertoli cells, the fibrocytes and the Leydig cells. a: HE staining, magnification $300 x$ b: Immunohistology, Vimentin, magnification 300x

Hodenbiopsie eines zehnjährigen Hengstes mit der klinischen Diagnose „Azoospermie". Aufgrund des nahezu ausschließlichen Vorkommens von Sertolizellen innerhalb der Tubuli seminiferi kann die Diagnose „Sertoli-cell-only-syndrome" gestellt werden. Zusätzlich ist eine Hyperplasie der Leydigzellen erkennbar. Eine Expression von Vimentin liegt in Sertolizellen, Fibrozyten und Leydigzellen vor.

a: HE Färbung, Vergrößerung 300x; b: Immunhistologie, Vimentin, Vergrößerung 300x

In biopsy samples of the two testicular neoplasms typical signs of a seminoma occured: the nuclei of the neoplastic cells varied in size, a few mitotic figures were obvious, the cells had a scant and slightly basophilic cytoplasm and indistinct cell boundaries. Partially the tubular walls had been destructed.

Therapeutical castration of stallions with acute orchitis (fig. 1), testicular cyst or testicular tumour (table 1: no. 1, 3, 4, 6) was without complications.

Following testicular biopsy, no clinical or ultrasonographically detectable signs of haemorrhage or inflammation such as swelling of testis and scrotum, pain and elevated body temperature could be detected during daily observations for three days. Laboratory findings did not reveal leukocytosis in any of the stallions. All stallions or geldings were discharged from the cli- nic. Stallion no. 6 (table 1) with bilateral testicular tumour was euthanized later without therapy on the wishes of the owner.

\section{Discussion}

The evaluation of the reproductive tract of the stallion is based on clinical examination combined with semen evaluation, bacteriological cultures and hormonal assays. In addition, transscrotal ultrasonography is an easy to perform diagnostic aid and may allow the differentiation of intra- and extratesticular disorders.

Transscrotal ultrasonography could be carried out in all stallions in this study restrained in an open-sided stock 
without sedation. Each testis was examined systematically according to Love (1992).

In the stallions of group 1, the absence of pathological changes in the anatomy of the testes, visualized through ultrasonography, was confirmed by histological investigation. In all biopsy samples examined alterations were absent, the seminiferous epithelium showed active signs of morphological intact spermatogenesis (fig. 7).

In agreement with Weidmann (1998), the diagnostic sensitivity of testicular ultrasonography in abnormalities such as testicular tumors, cystic disorders and scrotal fluid accumulation was found to be very high so that a definite diagnosis could be made in those cases without further invasive procedures. In contrast to this, there seems to be no relationship between the ultrasonographical appearance of homogenous or inhomogenous testicular parenchyma and changes in the daily sperm production or the daily sperm output. Similiar results were obtained in man (Behre et al. 1996). However, here, an ultrasonographically inhomogenous testicular parenchyma was found to indicate a severe disruption in spermatogenesis (Kliesch et al. 1998; Lederle et al. 1998).

First results have been obtained by our group in the study of ultrasonographic images of the equine testis using computer assisted grey scale analysis as has been described in

Tab. 1: Ultrasonographical and patho-histological results in nine stallions with clinically detectable disorders of the testis or azoospermia (group 2).

Sonographische und patho-histologische Befunde bei neun Hengsten mit klinisch abweichenden Hodenbefunden oder Azoospermie (Gruppe 2).

\begin{tabular}{|c|c|c|c|c|c|c|c|}
\hline nr. & $\begin{array}{l}\text { age } \\
\text { (years) }\end{array}$ & $\begin{array}{l}\text { clinical } \\
\text { findings }\end{array}$ & $\begin{array}{l}\text { semen } \\
\text { evaluation }\end{array}$ & $\begin{array}{l}\text { ultrasonographical } \\
\text { testicular findings }\end{array}$ & $\begin{array}{c}\text { testicular biopsy/ } \\
\text { patho-histological } \\
\text { indings }\end{array}$ & diagnosis & therapy \\
\hline 1 & 4 & $\begin{array}{c}\text { fever, asymmetric } \\
\text { scrotal swelling, } \\
\text { pain }\end{array}$ & not determined & $\begin{array}{c}\text { inhomogenous } \\
\text { parenchyma, } \\
\text { hyperechogenous spots }\end{array}$ & not determined & $\begin{array}{l}\text { acute unilateral } \\
\text { orchitis }\end{array}$ & $\begin{array}{l}\text { unilateral } \\
\text { castration }\end{array}$ \\
\hline 2 & 11 & $\begin{array}{l}\text { diffuse scrotal } \\
\text { enlargement } \\
\text { edema }\end{array}$ & not determined & $\begin{array}{l}\text { fibrin floating in free } \\
\text { fluid in scrotal cavity }\end{array}$ & not determined & $\begin{array}{c}\text { traumatic } \\
\text { haemoscrotum }\end{array}$ & $\begin{array}{l}\text { conservative } \\
\text { treatment }\end{array}$ \\
\hline 3 & 19 & $\begin{array}{c}\text { unilateral } \\
\text { testicular } \\
\text { enlargement } \\
\text { fibrous tissue, } \\
\text { scrotal pain }\end{array}$ & not determined & $\begin{array}{l}\text { heterogenous } \\
\text { parenchyma, } \\
\text { hypoechogenic } \\
\text { circumscribed } \\
\text { cloudy areas }\end{array}$ & $\begin{array}{l}\text { good biopsy } \\
\text { quality: } \\
\text { seminoma }\end{array}$ & $\begin{array}{l}\text { esticular tumour: } \\
\text { seminoma }\end{array}$ & $\begin{array}{l}\text { unilateral } \\
\text { castration }\end{array}$ \\
\hline 4 & 21 & $\begin{array}{l}\text { unilateral } \\
\text { testicular } \\
\text { enlargement, } \\
\text { scrotal pain }\end{array}$ & not determined & $\begin{array}{c}\text { heterogenous } \\
\text { parenchyma, } \\
\text { hypoechogenic } \\
\text { circumscribed area }\end{array}$ & $\begin{array}{l}\text { good biopsy } \\
\text { quality: } \\
\text { seminoma }\end{array}$ & $\begin{array}{l}\text { testicular } \\
\text { tumour: } \\
\text { seminoma }\end{array}$ & $\begin{array}{l}\text { unilateral } \\
\text { castration }\end{array}$ \\
\hline 5 & 20 & $\begin{array}{c}\text { bilateral } \\
\text { testicular } \\
\text { enlargement }\end{array}$ & oligozoospermia & $\begin{array}{l}\text { bilateral heterogenous } \\
\text { parenchyma }\end{array}$ & not determined & $\begin{array}{l}\text { bilateral } \\
\text { testicular } \\
\text { tumour }\end{array}$ & euthanasia \\
\hline 6 & 4 & $\begin{array}{l}\text { unilateral } \\
\text { testicular } \\
\text { enlargement, } \\
\text { fluctuation }\end{array}$ & not determined & $\begin{array}{c}\text { anechogenous } \\
\text { circumscribed area } \\
\text { within tunica albuginea }\end{array}$ & $\begin{array}{l}\text { low biopsy } \\
\text { quality: no } \\
\text { interpretation } \\
\text { available }\end{array}$ & testicular cyst & $\begin{array}{l}\text { bilateral } \\
\text { castration }\end{array}$ \\
\hline 7 & 10 & $\begin{array}{l}\text { subnormal } \\
\text { testicular } \\
\text { volume }\end{array}$ & azoospermia & $\begin{array}{l}\text { homogenous } \\
\text { echogenicity of } \\
\text { parenchyma }\end{array}$ & $\begin{array}{l}\text { good biopsy } \\
\text { quality: sertoli- } \\
\text { cell-only-syndrome }\end{array}$ & $\begin{array}{c}\text { testicular } \\
\text { hypoplasia/ } \\
\text { degeneration }\end{array}$ & $\begin{array}{l}\text { retired from } \\
\text { breeding }\end{array}$ \\
\hline 8 & 3 & $\begin{array}{l}\text { no gross } \\
\text { lesions }\end{array}$ & azoospermia & $\begin{array}{l}\text { homogenous } \\
\text { echogenocity of } \\
\text { parenchyma }\end{array}$ & $\begin{array}{l}\text { good biopsy quality: } \\
\text { sertoli-cell-only- } \\
\text { syndrome }\end{array}$ & $\begin{array}{c}\text { testicular } \\
\text { degeneration }\end{array}$ & $\begin{array}{l}\text { exclusion from } \\
\text { breeding }\end{array}$ \\
\hline 9 & 5 & $\begin{array}{l}\text { hemicastrated } \\
\text { due to inguinal } \\
\text { herniation, } \\
\text { compensatory } \\
\text { testicular } \\
\text { enlargement }\end{array}$ & azoospermia & $\begin{array}{l}\text { homogenous } \\
\text { echogenocity } \\
\text { of parenchyma }\end{array}$ & $\begin{array}{l}\text { good biopsy } \\
\text { quality: } \\
\text { germinal cell } \\
\text { atrophia, } \\
\text { arrested } \\
\text { spermatogenesis }\end{array}$ & $\begin{array}{c}\text { testicular } \\
\text { degeneration }\end{array}$ & $\begin{array}{l}\text { retired from } \\
\text { breeding }\end{array}$ \\
\hline
\end{tabular}


the equine endometrium (Lorber et al. 1999). These results show an improved interpretation and correlation with the spermatozoal output.

Due to the potential complications of testicular biopsy such as haemorrhage, inflammation, decrease in spermatozoal count or adhesions (Threlfall and Lopate 1993) indication for testicular biopsy should be limited to clinical cases where definite information as to the spermatogenic state of an infertile stallion can not be determined with less invasive evaluation techniques. With the exception of those cases with testicular degeneration, i.e. of the stallions of group 2, this study shows a diagnosis could be made with a routine investigation including clinical examination, seminal analysis and testicular ultrasonography.

These results in this investigation agree with those of Behre et al. (1996) and Bergmann and Kliesch (1998) in that a definite indication for the testicular biopsy is given in the differentiation of obstructive versus testicular azoospermia.

A biopsy technique should provide adequate tissue for patho-histological evaluation but should not be detrimental to future fertility. DelVento et al. (1992) could find no severe testicular damage caused by an open method of biopsy. However, a transitory increase in degeneration of spermatocytes and a mild inflammatory response at the biopsy site were accorded. A fine needle aspiration biopsy is less invasive but may be unsuitable for detailed histologic evaluation. In agreement with Hillman et al. (1994) and Faber and Roser (1998), excellent clinical results were obtained when samples were collected by means of an automated biopsy device. In addition to this, Faber and Roser (1998) demonstrated with a long term follow-up the absence of significant variations in the ejaculates or plasma hormone concentrations following testicular biopsy.

Although satisfying results could been have obtained in various studies with the biopsy carried out in the standing horse, a testicular biopsy under general anaesthesia was preferred in this investigation in order to obtain strict aseptic surgical conditions, optimal haemostasis and maximum safety for the stallion and the investigator.

In conclusion, testicular biopsy has proven to be a valuable aid in fertility evaluation with the automatic needle biopsy representing the method of choice as it has minimal adverse effects on the functional capability of the testis whilst maintaining sufficient quality of the tissue sample. Due to its invasive character, a biopsy is only indicated when less invasive techniques are inconclusive for infertility diagnosis.

Treatment of an unilateral testicular tumour or an unilateral orchitis was hemicastration. Bilateral castration was carried out in one stallion with a testicular cyst. A further stallion with a traumatically induced haemoscrotum was treated conservatively.

No treatment was performed in the stallions with azoospermia where maturation arrest was diagnosed due to the unknown aetiology and therefore the lack of a causal therapy. Analogous to findings in the rat (Yuan and McEntee 1987) severe testicular degeneration with a complete loss of germinal elements is supposed to be irreversible in stallions as well.

\section{Literature}

Behre, H.M., Yeung, C.H. and Nieschlag, E. (1996): Diagnostik der Infertilität und des Hypogonadismus. In: Nieschlag, E., and Behre, H.M. (Eds.): Andrologie: Grundlagen und Klinik der reproduktiven Gesundheit des Mannes. Springer, Berlin, Heidelberg, 91-117

Bergmann, M. and Kliesch, S. (1998): Hodenbiopsie. In: Krause, W., and Weidmann, W. (Eds.): Andrologie. Enke, Stuttgart, 66-71

Blanchard, T.L. and Varner, D.D. (1996): Evaluating breeding soundness in stallions - 4: Hormonal assay and testicular biopsy. Veterinary Medicine, 358-365

Brinkhoff, D. (1974): Hodenbiopsie beim Pferd: Untersuchungen zur Entnahme und Auswertung von aussagefähigem Organmaterial. Hannover, Tierärztl. Hochsch., Diss.

Dascanio, J.J. (1998): Examination of the scrotum, testes, prepuce and penis. In: Wolfe, D.F., and Moll, H.D. (Eds.): Large animal urogenital surgery. Williams and Wilkins, Baltimore, USA, 17-21

DelVento, V.R., Amann, R.P., Trotter, G.W., Rao Veeramachaneni, D.N. and Squires, E.L. (1992): Ultrasonographic and quantitative histologic assessment of sequelae to testicular biopsy in stallions. Am. J. Vet. Res. 53, 2094-2101

Faber, N.F. and Roser, J.F. (1998): Testicular biopsy in stallions: Effects on prospective fertility and diagnostic potentials. $7^{\text {th }}$ International Symposium on Equine Reproduction, Pretoria, South Africa, 12.07.-17.07.1998, $7-8$

Hillman, R.B., Casey, P.J., Kennedy, P.C., Hughes, J.P. and Liu, I.K.M. (1994): Testicular biopsy in the stallion. $6^{\text {th }}$ International Symposium on Equine Reproduction, Caxambu, Brazil, 07.-13.08.1994, 145-146

Ippensen, E., Klug-Simon, Ch. and Klug, E. (1972): Der Verlauf der Blutgefäße vom Hoden des Pferdes im Hinblick auf eine Biopsiemöglichkeit. Zuchthygiene 7, 35-45

Kliesch, S., Behre, H.M., Bergmann, M. and Nieschlag, E. (1998): Klinische Relevanz der Skrotalsonographie im Hinblick auf die Hodenhistologie bei Infertilitätspatienten. 10. Jahrestagung Deutsche Gesellschaft für Andrologie, Münster, 08.-10.10.1998, 37

Lederle, B., Keck, C., Raczek, S., Schneidt, R., Neulen, J. and Breckwoldt, M. (1998): Skrotale Ultrasonographie bei infertilen Männern. Fertilität 13, 227-232

Lorber, K.J., Bartmann, C.P., Klug, E. and Hermes, R. (1999): Examination of the equine endometrium with computer assisted Grey Scale Analysis (GSA). Reprod. Dom. Anim. 34, 31

Love, C.C. (1992): Ultrasonographic evaluation of the testis, epididymis, and spermatic cord of the stallion. Vet. Clinics North Am.: Equine Pract. 8, 167-182

Schill, W.-B. (1994): Fertilitätsstörungen des Mannes - Diagnostik und Therapie. In: Runnebaum, B., and Rabe, T. (Eds.): Gynäkologische Endokrinologie und Fortpflanzungsmedizin. Bd. 2 Fortpflanzungsmedizin. Springer, Berlin, Heidelberg, 287-335

Smith, J.A. (1974): Biopsy and the testicular artery of the horse. Equine vet. J. $6,81-83$

Threlfall, W.R. and Lopate, C. (1993): Testicular biopsy. In: McKinnon, A.O. and VosS, J.L. (Eds.): Equine reproduction. Lea \& Febiger, USA, 943-949

Weidmann, W. (1998): Bildgebende Diagnostik. In: Krause, W. and Weidmann, W. (Eds.): Andrologie. Enke, Stuttgart, 56-66

Wissdorf, H., Gerhards, H. und Harps, O. (1998): Männliche Geschlechtsorgane mit Hodenhüllen und Harnröhre. In: Wissdorf, $H$., Gerhards, H. Huskamp, B. (Hrsg.): Praxisorientierte Anatomie des Pferdes. Schaper, Alfeld, Hannover, 549-582

Yuan, Y.D. and McEntee, K. (1987): Testicular degeneration, rat. In: Jones, T.C. Mohr, U., Hunt, R.D. (Eds.): Genital System. Springer, Berlin, Heidelberg, 212-217

\section{Dr. Claus Peter Bartmann}

Klinik für Pferde

Tierärztliche Hochschule Hannover

Bischofsholer Damm 15

D-30173 Hannover

Tel.: 0511-8567233

Fax: 0511-8567688 